\title{
ANALISIS FAKTOR YANG MEMPENGARUHI PRODUKTIVITAS KERJA PEGAWAI PADA MASA PANDEMI COVID-19
}

\author{
Encep Saefullah ${ }^{1}$, Tabroni ${ }^{2}$ \\ 1,2 Universitas Bina Bangsa \\ encepsaefullah82@gmail.com
}

\begin{abstract}
ABSTRAK
Tujuan penelitian ini untuk mengetahui faktor paling dominan yang mempengaruhi Produktivitas Kerja Pegawai di Kecamatan Carita Kabupaten Pandeglang pada masa Pandemi Covid-19. Metode pengumpulan data yang digunakan dalam penelitian adalah metode kuisioner, sedangkan metode analisis menggunakan skala likert, dan rating scale. Dari tiga faktor yang mempengaruhi Produktivitas Kerja Pegawai di Kecamatan Carita Kabupaten Pandeglang pada masa Pandemi Covid-19, yaitu Pendidikan dan Pelatihan mendapat persepsi dari responden dengan kriteria setuju, sedangkan Motivasi mendapat persepsi dari responden dengan kriteria sangat setuju artinya ketiga faktor tersebut mempengaruhi produktivitas kerja pegawai. Faktor yang paling dominan mempengaruhi Produktivitas Kerja Pegawai di Kecamatan Carita Kabupaten Pandeglang pada masa Pandemi Covid-19 adalah Motivasi, karena mempunyai nilai rata-rata paling tinggi diantara kedua faktor lainnya yaitu 175,5 , hal ini menunjukkan bahwa motivasi memiliki peranan penting dan merupakan kondisi yang menggerakan diri pegawai yang terarah untuk mencapai tujuan organisasi.
\end{abstract}

Kata kunci: Faktor yang Mempengaruhi Produktivitas Kerja Pegawai, Pandemi Covid-19

\section{ABSTRACT}

The purpose of this study was to determine the most dominant factors affecting employee work productivity in Carita District, Pandeglang Regency during the Covid-19 Pandemic. The data collection method used in this research is the questionnaire method, while the analysis method uses a Likert scale and rating scale. Of the three factors that affect Employee Work Productivity in Carita Subdistrict, Pandeglang Regency during the Covid-19 Pandemic, namely Education and Training received perceptions from respondents with agreed criteria, while Motivation received perceptions from respondents with strongly agree criteria meaning that these three factors affect employee work productivity. The most dominant factor influencing Employee Work Productivity in Carita Subdistrict, Pandeglang Regency during the Covid-19 Pandemic is Motivation, because it has the highest average value among the other two factors, namely 175.5, this shows that motivation has an important role and is a condition self-directed employees to achieve organizational goals.

Keywords: Factors Affecting Employee Work Productivity, Covid-19 Pandemic

\section{PENDAHULUAN}

Pada masa pandemi Covid-19 kegiatan masyarakat sangat dibatasi untuk mencegah penyebaran virus Covid-19. Pandemi juga menyebabkan pelayanan terhadap masyarakat secara langsung di batasi, sehingga setiap organisasi menggunakan cara digitalisasi secara online dalam pelayanannya kepada masyarakat. Digitalisasi pada setiap pelayanan terhadap masyarakat dapat mempengaruhi kegiatan pegawai dalam melayani masyarakat. Infrastruktur 
dan perangkat pendukung dibutuhkan dalam melakukan kegiatan pelayanan online terhadap masyarakat pada masa pandemi ini. Perangkat yang ada tidak dapat berjalan dengan sendirinya, dibutuhkan sumber daya manusia yang kompeten dalam bidangnya agar pelayanan terhadap masyarakat dapat terlaksana dengan maksimal dan tanpa kendala.

Sumber daya manusia harus di kembangkan, karena beda dengan mesin yang selalu melakukan aktivitas yang sama setiap waktu, sumber daya manusia selalu mengalami perubahan dan perkembangan, karna perubahan yang terjadi tersebut akan dapat menimbulkan berbagai jenis tantangan yang harus dihadapi dan di atasi dengan baik oleh organisasi, pencapaian tujuan organisasi akan terlaksana bila sumber daya manusianya menujukan performa kerja yang tinggi. Sumber daya manusia mempunyai peranan penting dalam aktivitas, karena bagaimanapun juga kemajuan suatu organisasi tidak terlepas dari peran dan kemampuan sumber daya manusia yang baik.

Salah satu faktor dalam sebuah organisasi yang harus mendapat perhatian pihak manajemen adalah produktivitas kerja pegawai. Menurut Malayu Hasibuan (2008) Produktivitas adalah perbandingan antara keluaran (output) dengan masukan (input), jika produktivitas naik hanya dimungkinkan oleh adanya peningkatan efisiensi (waktu-bahantenaga) dan sistem kerja, teknik produksi dan adanya peningkatan keterampilan dari tenaga kerja. Sedangkan menurut Ravianto (2014), Produktivitas adalah ukuran efisiensi dengan nama modal, material, peralatan atau teknologi, manajemen SDM, informasi dan waktu yang digunakan untuk menghasilkan barang dan jasa. Produktivitas diartikan sebagai hubungan antara keluaran (barang atau jasa) dengan masukan (tenaga kerja, bahan, uang).

Secara sederhana produktivitas adalah hubungan antara kualitas yang dihasilkan dengan jumlah kerja yang dilakukan untuk mencapai hasil itu. Sedangkan secara umum adalah bahwa produktivitas merupakan rasio antara kepuasan atas kebutuhan dan pengorbanan yang dilakukan (Encep Saefullah, et al, 2017). Produktivitas kerja penting bagi organisasi untuk mencapai tujuan dengan efisien dan efektif dan sesuai dengan harapan (Tjutju Yuniarsih dan Suwatno, 2016).

Produktivitas adalah ukuran efisiensi produktif. Suatu perbandingan antara hasil keluaran dan masukan. Masukan sering dibatasai dengan tenaga kerja sedangkan keluaran diukur dalam kesatuan fisik, bentuk dan nilai (Sutrisno, 2019). Secara teknis produktivitas merupakan perbandingan antara hasil yang dicapai dan keseluruhan sumber daya yang dipergunakan, produktivitas tenaga kerja merupakan perbandingan antara hasil yang dicapai dengan pasar tenaga kerja per satuan waktu dan sebagai tolok ukur jika ekspansi dan aktifitas dari sikap sumber yang digunakan selama produktivitas berlangsung dengan membandingkan 
Prosiding The 1st National Conference on Applied Business, Education, \& Technology (NCABET)",

Unversitas Bina Bangsa 2021

DOI Article : 10.46306/ncabet.vlil.23

jumlah yang dihasilkan dengan setiap sumber yang digunakan. Produktivitas dapat diukur dengan dua standar utama, yaitu produktivitas fisik dan produktivitas nilai. Secara fisik produktivitas diukur secara kuantitatif seperti banyaknya keluaran (panjang, berat, lamanya waktu, jumlah). Sedangkan berdasarkan nilai, produktivitas diukur atas dasar nilai-nilai kemampuan, sikap, perilaku, disiplin, motivasi dan komitmen terhadap pekerjaan/tugas.

Peningkatan produktivitas kerja pegawai terutama pada masa pandemi Covid-19 dapat dilihat sebagai masalah keperilakuan, tetapi juga dapat mengandung aspek-aspek teknis. Mengatasi hal itu perlu pemahaman yang tepat tentang faktor-faktor penentu keberhasilan meningkatkan produktivitas kerja pegawai. Menurut Sunyoto (2012) ada beberapa faktor yang mempengaruhi produktivitas kerja pegawai, yaitu Pendidikan, Pelatihan dan Motivasi.

1. Pendidikan. Pendidikan adalah salah satu kegiatan untuk meningkatkan pengetahuan umum seseorang, termasuk di dalamnya peningkatan penguasaan teori dan keterampilan memutuskan terhadap persoalan-persoalan yang menyangkut kegiatan dalam mencapai suatu tujuan (Heidjrachman dalam Yuniarsih dan Suwatno, 2011).

2. Pelatihan. Pelatihan adalah proses sistematik pengubahan perilaku para pegawai dalam suatu arah guna meningkatkan tujuan-tujuan organisasional. Pelatihan biasanya dimulai dengan orientasi yakni suatu proses dimana para pegawai diberi informasi dan pengetahuan tentang kepegawaian, organisasi dan harapan-harapan untuk mencapai performance tertentu (Sulistiyani dan Rosidah, 2009).

3. Motivasi. Motivasi adalah pemberian daya penggerak yang menciptakan kegairahan kerja seseorang agar mereka mampu bekerjasama, bekerja efektif, dan terintegritas dengan segala daya upayanya untuk mencapai kepuasan (Hafidzi et al, 2019).

Masing-masing faktor mempunyai pengaruh tersendiri pada masing-masing pegawai, dan dalam setiap organisasi masing-masing faktor tersebut mempunyai pengaruh yang berbeda, karena tergantung keadaan organisasi tersebut.

Kecamatan Carita adalah salah satu organisasi/instansi pemerintahan yang beralamat di Jalan Sumur Dawa Kampung Cibeureum Desa Carita Kecamatan Carita Kabupaten Pandeglang. Kecamatan mempunyai tugas melaksanakan sebagian kewenangan Pemerintah Kabupaten di wilayah kerjanya, yang mencakup bidang pemerintahan, ekonomi, pembangunan, kesejahteraan rakyat dan pembinaan kehidupan masyarakat serta urusan pelayanan umum lainnya.

\section{METODE PENELITIAN}




\section{Teknik Pengumpulan Data}

Metode pengumpulan data yang digunakan dalam penelitian adalah metode kuisioner. Kuisioner dalam bentuk daftar pernyataan disebarkan kepada seluruh Pegawai di Kecamatan Carita Kabupaten Pandeglang. Sedangkan metode analisis menggunakan skala likert, dan rating scale. Menurut Sugiyono (2016), Skala likert digunakan untuk mengukur sikap, pendapat dan persepsi seseorang atau sekelompok orang tentang fenomena sosial yang terjadi.

\section{Populasi dan Sampel}

Populasi dan sampel dalam penelitian ini adalah seluruh Pegawai di Kecamatan Carita Kabupaten Pandeglang yang berjumlah 40 orang.

\section{Kerangka Analisis}

\begin{tabular}{|l|l|l|}
\hline $\begin{array}{l}\text { Faktor yang Mempengaruhi } \\
\text { Produktivitas Kerja Pegawai: } \\
\text { 1. Pendidikan } \\
\text { 2. Pelatihan } \\
\text { 3. Motivasi } \\
\text { (Sunyoto, 2012) }\end{array}$ & $\rightarrow \begin{array}{l}\text { Faktor yang paling } \\
\text { Dominan } \\
\text { Persepsi } \\
\text { Pegawai }\end{array}$ & $\begin{array}{l}\text { Mempengaruhi } \\
\text { Produktivitas Kerja } \\
\text { Pegawai }\end{array}$ \\
\hline
\end{tabular}

\section{Gambar 1. Kerangka Analisis}

\section{HASIL DAN PEMBAHASAN}

\section{Karakteristik Responden}

Dari hasil kuisioner diperoleh informasi tentang karakterisitik 40 orang responden yang merupakan sampel dalam penelitian ini. Adapun karakteristik responden tersebut sebagai berikut:

a. Karakteristik responden berdasarkan jenis kelamin.

Tabel 1. Karakteristik Responden Berdasarkan Jenis Kelamin

\begin{tabular}{|c|c|c|c|}
\hline No & Jenis Kelamin & Frekuensi (Orang) & Persentase (\%) \\
\hline 1 & Laki - Laki & 36 & 90 \\
\hline 2 & Perempuan & 4 & 10 \\
\hline & Jumlah & 40 & 100 \\
\hline
\end{tabular}

Sumber: Data Penelitian, 2021

Dari tabel 1 di atas diketahui 36 orang atau 90\% sampel dalam penelitian ini adalah laki-laki, dan 4 orang atau $10 \%$ berjenis kelamin perempuan.

b. Karakteristik responden berdasarkan pendidikan.

\section{Tabel 2. Karakteristik Responden Berdasarkan Pendidikan}


Prosiding The 1st National Conference on Applied Business, Education, \& Technology (NCABET)"

Unversitas Bina Bangsa 2021

DOI Article : 10.46306/ncabet.v1i1.23

\begin{tabular}{|c|c|c|c|}
\hline No & Pendidikan & Frekuensi (Orang) & Persentase (\%) \\
\hline 1 & SMA & 19 & $47.5 \%$ \\
\hline 2 & S1 & 18 & $45 \%$ \\
\hline 3 & S2 & 3 & $7.5 \%$ \\
\hline \multicolumn{2}{|c|}{ Jumlah } & $\mathbf{4 0}$ & $\mathbf{1 0 0}$ \\
\hline
\end{tabular}

Sumber: Data Penelitian, 2021

Tabel 2 di atas menunjukkan bahwa pendidikan responden yang terbanyak adalah SMA yaitu 19 orang atau 47,5\% dari jumlah sampel, diikuti S1 berjumlah 18 orang atau $45 \%$ dan S2 berjumlah 3 orang atau 7,5\%.

c. Karakteristik responden berdasarkan usia.

Tabel 3. Karakteristik Responden Berdasarkan Usia

\begin{tabular}{|c|c|c|c|}
\hline No & Usia & Frekuensi (Orang) & Persentase $(\%)$ \\
\hline 1 & $20-29$ & 1 & $2.5 \%$ \\
\hline 2 & $30-39$ & 7 & $17.5 \%$ \\
\hline 3 & $40-50$ & 21 & $52.5 \%$ \\
\hline 4 & $>50$ & 11 & $27.5 \%$ \\
\hline \multicolumn{2}{|c|}{ Jumlah } & 40 & 100 \\
\hline
\end{tabular}

Sumber: Data Penelitian, 2021

Dari tabel 3 di atas sesuai dengan usia bahwa mayoritas responden berusia 40-50 tahun, yaitu 21 orang atau 52,5\% dari jumlah sampel, selanjutnya usia $>50$ tahun sebanyak 11 orang atau 27,5\%, usia 30-39 tahun sebanyak 7 orang atau 17,5\% dan usia 20-29 tahun sebanyak 1 orang atau $2,5 \%$.

d. Karakteristik responden berdasarkan masa kerja.

Tabel 4. Karakteristik Responden Berdasarkan Masa Kerja

\begin{tabular}{|c|c|c|c|}
\hline No & Masa Kerja & Frekuensi (Orang) & Persentase (\%) \\
\hline 1 & $1-10$ & 2 & $5 \%$ \\
\hline 2 & $11-20$ & 34 & $85 \%$ \\
\hline 3 & $>20$ & 4 & $10 \%$ \\
\hline \multicolumn{2}{|l|}{ Jumlah } & $\mathbf{4 0}$ & $\mathbf{1 0 0}$ \\
\hline
\end{tabular}

Sumber: Data Penelitian, 2021

Dari tabel 4 di atas berdasarkan masa kerja bahwa responden yang masa kerjanya 1120 tahun paling banyak yaitu 34 orang atau $85 \%$ dari jumlah sampel, selanjutnya masa kerja $>20$ tahun sebanyak 4 orang atau 10\%, dan masa kerja 1-10 tahun sebanyak 2 orang atau 5\%. 


\section{Persepsi Responden Terhadap Faktor yang Mempengaruhi Produktivitas Kerja Pegawai}

Dari hasil kuisioner yang disebarkan kepada 40 orang Pegawai di Kecamatan Carita Kabupaten Pandeglang sebagai sampel dalam penelitian ini, diketahui persepsi responden terhadap faktor yang mempengaruhi produktivitas kerja pegawai, sebagai berikut:

a. Persepsi responden terhadap faktor pendidikan

Berikut ini persepsi responden tentang faktor pendidikan seperti pada tabel 5.

Tabel 5. Persepsi Responden Terhadap Faktor Pendidikan

\begin{tabular}{|c|c|c|c|c|c|c|c|c|}
\hline \multirow{2}{*}{ No } & \multirow{2}{*}{ Pernyataan } & \multicolumn{5}{|c|}{ Tanggapan Responden } & \multirow{2}{*}{ Jmlh } & \multirow{2}{*}{ Kriteria } \\
\hline & & SS & ST & RG & TS & STS & & \\
\hline 1. & $\begin{array}{l}\text { Pengetahuan yang } \\
\text { diperoleh dari pendidikan } \\
\text { formal harus dievaluasi } \\
\text { secara periodik }\end{array}$ & 12 & 20 & 5 & 1 & 2 & 159 & Setuju \\
\hline 2. & $\begin{array}{l}\text { Pimpinan beserta staf } \\
\text { memiliki latar belakang } \\
\text { pendidikan yang sesuai } \\
\text { dengan bidangnya }\end{array}$ & 10 & 18 & 8 & 2 & 2 & 152 & Setuju \\
\hline 3. & $\begin{array}{l}\text { Seseorang yang pernah } \\
\text { mengenyam pendidikan } \\
\text { baik formal ataupun } \\
\text { informal dapat mengatasi } \\
\text { kesulitan-kesulitan yang } \\
\text { muncul }\end{array}$ & 15 & 17 & 5 & 2 & 1 & 163 & $\begin{array}{l}\text { Sangat } \\
\text { Setuju }\end{array}$ \\
\hline 4. & $\begin{array}{lr}\text { Pendidikan } & \text { berkelanjutan } \\
\text { dapat } & \text { meningkatkan } \\
\text { keahlian dan pengetahuan } \\
\text { seorang pegawai }\end{array}$ & 13 & 21 & 3 & 2 & 1 & 163 & $\begin{array}{l}\text { Sangat } \\
\text { Setuju }\end{array}$ \\
\hline \multicolumn{7}{|c|}{ Rata-Rata } & 159,25 & Setuju \\
\hline
\end{tabular}

Sumber: Data Penelitian, 2021

Keterangan:

$0-40=$ Sangat Tidak Setuju

$41-80=$ Tidak Setuju

$81-120=$ Ragu-Ragu

$121-160=$ Setuju

$161-200=$ Sangat Setuju

Tabel 5 di atas menunjukkan persepsi 40 orang responden secara rata-rata menyatakan setuju bahwa produktivitas kerja pegawai di Kecamatan Carita Kabupaten Pandeglang dipengaruhi oleh faktor pendidikan, dengan nilai rata-rata 159,25.

b. Persepsi responden terhadap faktor pelatihan

Berikut persepsi responden terhadap faktor pelatihan, seperti pada tabel 6 .

Tabel 6. Persepsi Responden Terhadap Faktor Pelatihan 
Prosiding The 1st National Conference on Applied Business, Education, \& Technology (NCABET)"

Unversitas Bina Bangsa 2021

DOI Article : 10.46306/ncabet.vli1.23

\begin{tabular}{|c|c|c|c|c|c|c|c|c|}
\hline \multirow{2}{*}{ No } & \multirow{2}{*}{ Pernyataan } & \multicolumn{5}{|c|}{ Tanggapan Responden } & \multirow{2}{*}{ Jmlh } & \multirow{2}{*}{ Kriteria } \\
\hline & & SS & ST & RG & TS & STS & & \\
\hline 1. & $\begin{array}{l}\text { Materi teoritis dan praktek } \\
\text { pelatihan yang saya } \\
\text { dapatkan sudah dapat } \\
\text { memenuhi kebutuhan } \\
\text { standar dalam memahami } \\
\text { pekerjaan yang saya hadapi }\end{array}$ & 10 & 19 & 9 & 1 & 1 & 156 & Setuju \\
\hline 2. & $\begin{array}{l}\text { Pelatihan yang pernah } \\
\text { saya ikuti dapat } \\
\text { membantu saya dalam } \\
\text { pemanfaatan sistem yang } \\
\text { digunakan }\end{array}$ & 10 & 17 & 10 & 2 & 1 & 153 & Setuju \\
\hline 3. & $\begin{array}{l}\text { Saya mengikuti pelatihan } \\
\text { agar dapat memperbaiki } \\
\text { prestasi kerja pada } \\
\text { pekerjaan yang menjadi } \\
\text { tanggung jawab saya }\end{array}$ & 15 & 20 & 4 & 1 & - & 169 & $\begin{array}{l}\text { Sangat } \\
\text { Setuju }\end{array}$ \\
\hline 4. & $\begin{array}{l}\text { Pelatihan yang saya ikuti } \\
\text { mampu meningkatkan } \\
\text { etos kerja yang lebih baik } \\
\text { dan membantu saya dalam } \\
\text { menyesuaikan diri di } \\
\text { tempat kerja }\end{array}$ & 13 & 19 & 4 & 3 & 1 & 160 & Setuju \\
\hline \multicolumn{7}{|c|}{ Rata-Rata } & 159,5 & Setuju \\
\hline
\end{tabular}

Sumber: Data Penelitian, 2021

Keterangan:

$0-40=$ Sangat Tidak Setuju

$41-80=$ Tidak Setuju

$81-120=$ Ragu-Ragu

$121-160=$ Setuju

$161-200 \quad=$ Sangat Setuju

Tabel 6 di atas menunjukkan persepsi 40 orang responden secara rata-rata menyatakan setuju bahwa produktivitas kerja pegawai di Kecamatan Carita Kabupaten Pandeglang dipengaruhi oleh faktor pelatihan, dengan nilai rata-rata 159,5.

c. Persepsi responden terhadap faktor motivasi

Berikut persepsi responden terhadap faktor motivasi, seperti pada tabel 7.

Tabel 7. Persepsi Responden Terhadap Faktor Motivasi 


\begin{tabular}{|c|c|c|c|c|c|c|c|c|}
\hline \multirow{2}{*}{ No } & \multirow{2}{*}{ Pernyataan } & \multicolumn{5}{|c|}{ Tanggapan Responden } & \multirow{2}{*}{ Jmlh } & \multirow{2}{*}{ Kriteria } \\
\hline & & SS & ST & RG & TS & STS & & \\
\hline 1. & 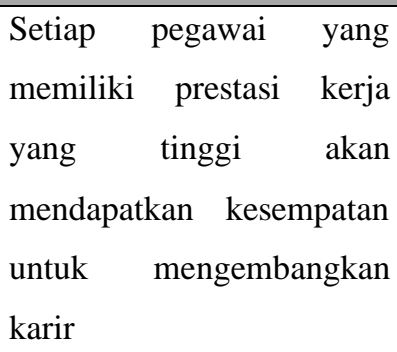 & 15 & 21 & 3 & 1 & - & 170 & $\begin{array}{l}\text { Sangat } \\
\text { Setuju }\end{array}$ \\
\hline 2. & $\begin{array}{l}\text { Pegawai memiliki } \\
\text { kesempatan untuk } \\
\text { mengikuti pendidikan dan } \\
\text { pelatihan untuk } \\
\text { menunjang prestasi }\end{array}$ & 16 & 21 & 2 & 1 & - & 172 & $\begin{array}{l}\text { Sangat } \\
\text { Setuju }\end{array}$ \\
\hline 3. & $\begin{array}{lr}\text { Pegawai } & \text { memiliki } \\
\text { kewenangan } & \text { dan } \\
\text { tanggungjawab terhadap } \\
\text { keberhasilan kantor }\end{array}$ & 18 & 20 & 1 & 1 & - & 175 & $\begin{array}{l}\text { Sangat } \\
\text { Setuju }\end{array}$ \\
\hline 4. & $\begin{array}{lr}\text { Dalam } & \text { mengerjakan } \\
\text { pekerjaan } & \text { setiap pegawai } \\
\text { ingin } & \text { mendapat } \\
\text { pengakuan } & \text { terhadap } \\
\text { pekerjaannya } & \text { dari } \\
\text { pimpinan dan } & \text { masyarakat }\end{array}$ & 25 & 15 & - & - & - & 185 & $\begin{array}{l}\text { Sangat } \\
\text { Setuju }\end{array}$ \\
\hline & & Rat & & & & & 175,5 & $\begin{array}{l}\text { Sangat } \\
\text { Setuju }\end{array}$ \\
\hline
\end{tabular}

Sumber: Data Penelitian, 2021

Keterangan:

$0-40=$ Sangat Tidak Setuju

$41-80=$ Tidak Setuju

$81-120=$ Ragu-Ragu

$121-160=$ Setuju

$161-200=$ Sangat Setuju

Tabel 7 di atas menunjukkan persepsi 40 orang responden secara rata-rata menyatakan sangat setuju bahwa produktivitas kerja pegawai di Kecamatan Carita Kabupaten Pandeglang dipengaruhi oleh faktor motivasi, dengan nilai rata-rata 175,5.

Secara rinci persepsi responden terhadap faktor yang mempengaruhi Produktivitas Kerja Pegawai di Kecamatan Carita Kabupaten Pandeglang, sebagai berikut:

a. Pendidikan 
Prosiding The 1st National Conference on Applied Business, Education, \& Technology (NCABET)",

Unversitas Bina Bangsa 2021

DOI Article : 10.46306/ncabet.v1i1.23

Hasil penelitian pada tabel 5 diperoleh nilai rata-rata persepsi responden terhadap variabel pendidikan sebesar 159,25 berada pada interval 121-160 dengan kriteria setuju. Nilai ini menunjukkan produktivitas kerja yang baik akan dipengaruhi oleh faktor pendidikan, bahwa untuk menghasilkan produktivitas kerja yang baik, seorang pegawai harus memiliki latar belakang pendidikan yang sesuai dengan jenis pekerjaan dan jabatannya, hal ini dibutuhkan untuk menghasilkan produktivitas kerja pegawai yang optimal sesuai dengan yang diharapkan, baik oleh instansi ataupun oleh masyarakat terutama pada saat pandemi Covid-19 sekarang ini.

b. Pelatihan

Hasil penelitian tentang persepsi responden terhadap faktor pelatihan pada tabel 6 diketahui bahwa pelatihan merupakan salah satu faktor yang sangat mempengaruhi Produktivitas Kerja Pegawai di Kecamatan Carita Kabupaten Pandeglang, dengan nilai ratarata 159,5 dan berada pada interval 121-160 dengan kriteria setuju.

Bahwa untuk menghasilkan produktivitas kerja yang baik, seorang pegawai harus mempunyai kemampuan yang ditunjukkan oleh keterampilan dan kompetensinya serta dengan mengikuti pelatihan, pegawai diharapkan mampu menyelesaikan pekerjaan dengan lebih mudah dan cepat karena sudah lebih memahami tentang tugas dan tanggung jawab pekerjaannya, terlebih pada saat pandemi Covid-19 ini segala sesuatu baik pelayanan ataupun lainnya sudah serba online, maka pegawai dituntut harus mampu mengoperasikan sistem pelayanan berbasis online tersebut.

c. Motivasi

Hasil penelitian tentang persepsi responden terhadap faktor motivasi pada tabel 7 diketahui bahwa motivasi merupakan faktor yang sangat mempengaruhi Produktivitas Kerja Pegawai di Kecamatan Carita Kabupaten Pandeglang, dengan nilai rata-rata 175,5 dan berada pada interval 161-200 dengan kriteria sangat setuju.

Motivasi merupakan penggerak yang mengarahkan pada tujuan dan setiap organisasi tentu ingin mencapai tujuan. Untuk mencapai tujuan tersebut, peranan manusia yang terlibat didalamnya sangatlah penting. Untuk menggerakkan manusia agar sesuai dengan yang di kehendaki organisasi, maka haruslah dipahami motivasi manusia yang bekerja didalam organisasi tersebut, karena motivasi inilah yang menentukan perilaku orang-orang untuk bekerja, atau dengan kata lain perilaku merupakan cerminan yang paling sederhana dari motivasi, seseorang akan berperilaku sesuai dengan dorongan yang dimiliki dan apa yang mendasari perilakunya. 
Faktor yang Paling Dominan Mempengaruhi Produktivitas Kerja Pegawai di Kecamatan Carita Kabupaten Pandeglang

Dari hasil penelitian dan pembahasan tentang faktor yang mempengaruhi Produktivitas Kerja Pegawai di Kecamatan Carita Kabupaten Pandeglang. Adapun faktor yang menjadi fokus dalam penelitian dan nilai yang diperoleh dari persepsi responden dikumpul lewat kuisioner dan diolah seperti pada tabel 5-7. Untuk menentukan faktor yang paling dominan mempengaruhi produktivitas kerja pegawai akan diurut seperti pada tabel 8 .

Tabel 8. Nilai Rata-Rata Faktor yang Mempengaruhi Produktivitas Kerja

\begin{tabular}{|l|c|c|}
\hline \multicolumn{1}{|c|}{$\begin{array}{c}\text { Faktor yang Mempengaruhi } \\
\text { Produktivitas Kerja }\end{array}$} & $\begin{array}{c}\text { Jumlah Skor } \\
\text { Rata-Rata }\end{array}$ & Kriteria \\
\hline Pendidikan & 159,25 & Setuju \\
\hline Pelatihan & 159,5 & Setuju \\
\hline Motivasi & 175,5 & \\
\hline Jumlah Skor & 494,25 & Sangat Setuju \\
\hline Rata-Rata & 164,75 & \\
\hline
\end{tabular}

Sumber: Tabel 5-7 Diolah, 2021

Keterangan:

$0-40=$ Sangat Tidak Setuju

$41-80=$ Tidak Setuju

$81-120=$ Ragu-Ragu

$121-160=$ Setuju

$161-200=$ Sangat Setuju

Dari tabel 8 di atas diketahui bahwa faktor yang paling dominan mempengaruhi Produktivitas Kerja Pegawai di Kecamatan Carita Kabupaten Pandeglang adalah faktor motivasi dengan jumlah nilai rata-rata dari persepsi responden 175,5 dengan kriteria sangat setuju. Untuk lebih jelas akan diurut dengan menggunakan rating scale, seperti pada tabel 9 di bawah ini:

Tabel 9. Perengkingan Faktor yang Mempengaruhi Produktivitas Kerja

\begin{tabular}{|c|c|}
\hline Nomor Rangking & Faktor yang Mempengaruhi Produktivitas Kerja \\
\hline I & Motivasi \\
\hline II & Pelatihan \\
\hline III & Pendidikan \\
\hline
\end{tabular}

Sumber: Tabel 8, Diolah, 2021

Dari Tabel 9 di atas menunjukkan bahwa motivasi sangat mempengaruhi Produktivitas 
Prosiding The 1st National Conference on Applied Business, Education, \& Technology (NCABET)",

Unversitas Bina Bangsa 2021

DOI Article : 10.46306/ncabet.v1il.23

Kerja Pegawai di Kecamatan Carita Kabupaten Pandeglang, ini menunjukkan bahwa jika motivasi kerja pegawai naik akan berdampak pada semakin tinggi produktivitas kerja pegawai itu sendiri.

Sedangkan faktor pendidikan dan pelatihan memperoleh skor persepsi dari responden lebih rendah dari motivasi tetapi masih dalam kategori setuju, artinya bahwa untuk menghasilkan produktivitas kerja yang baik, seorang pegawai harus mempunyai kemampuan yang ditunjukkan oleh pengetahuan, keterampilan dan kompetensinya melalui pendidikan, baik formal maupun informal, pelatihan-pelatihan, baik yang dilaksanakan oleh instansinya maupun pelatihan yang diadakan diluar instansinya, sehingga dengan mengikuti banyak pendidikan dan pelatihan, pegawai diharapkan mampu menyelesaikan pekerjaan dengan lebih mudah dan cepat karena sudah lebih memahami tentang tugas dan tanggung jawab pekerjaannya.

Dari hasil pembahasan di atas menunjukkan bahwa ke tiga faktor yang menjadi fokus penelitian ini mendapat persepsi dari responden dengan nilai rata-rata 164,75 dengan kriteria sangat setuju, artinya ke tiga faktor yang mempengaruhi produktivitas kerja pegawai, yaitu pendidikan, pelatihan dan motivasi mempengaruhi Produktivitas Kerja Pegawai di Kecamatan Carita Kabupaten Pandeglang.

\section{KESIMPULAN}

Dari hasil penelitian dan pembahasan dapat ditarik beberapa kesimpulan, sebagai berikut:

1. Dari tiga faktor yang mempengaruhi Produktivitas Kerja Pegawai di Kecamatan Carita Kabupaten Pandeglang, yaitu pendidikan, pelatihan dan motivasi mendapat persepsi dari responden dengan kriteria sangat setuju, dengan nilai rata-rata 164,75, artinya ketiga faktor tersebut mempengaruhi produktivitas kerja pegawai.

2. Faktor yang paling dominan mempengaruhi Produktivitas Kerja Pegawai di Kecamatan Carita Kabupaten Pandeglang adalah motivasi, karena mempunyai nilai rata-rata paling tinggi dari dua faktor lainnya, yaitu 175,5 dan berada pada interval 161-200 dengan kriteria sangat setuju.

\section{UCAPAN TERIMA KASIH}

Penulis berterima kasih kepada Universitas Bina Bangsa khususnya kepada Rektor Universitas Bina Bangsa yang telah memberikan support dan dukungan terhadap penelitian ini, sehingga penelitian ini bisa terselesaikan. 


\section{DAFTAR PUSTAKA}

Adha, R. N., Qomariah, N., \& Hafidzi, A. H. (2019). Pengaruh Motivasi Kerja, Lingkungan Kerja, Budaya Kerja Terhadap Kinerja Karyawan Dinas Sosial Kabupaten Jember. Jurnal Penelitian IPTEKS, 4 (1), 47-62.

Ambar, Teguh Sulistiyani dan Rosidah. (2009). Manajemen Sumber Daya Manusia. Yogyakarta: Graha Ilmu.

Hasibuan, Malayu S.P. (2008). Organisasi dan Motivasi, Jakarta: Bumi Aksara.

Ravianto J. (2014). Produktivitas dan Pengukuran, Jakarta: Binaman Aksara

Saefullah, Encep, et al. (2017). Pengaruh Beban Kerja dan Stres Kerja Terhadap Produktivitas Kerja Karyawan, Akademika, Jurnal Manajemen, Akuntansi dan Bisnis, 15 (2). DOI: http://dx.doi.org/10.51881/jam.v15i2.81

Sugiyono. (2016). Metode Penelitian Kuantitatif, Kualitatif dan R\&D. Bandung: PT Alfabeta.

Sunyoto, Danang. (2012). Manajemen Sumber Daya Manusia. Jakarta: PT Buku Seru.

Sutrisno, Edy, (2019). Manajemen Sumber Daya Manusia. Jakarta: Prenadamedia.

Yuniarsih, Tjuju dan Suwanto. (2011). Manajemen Sumber Daya Manusia. Bandung: PT. Alfabeta.

Yuniarsih, Tjuju dan Suwatno. (2016). Manajemen Sumber Daya Manusia Teori, Aplikasi, dan Isu Penelitian. Bandung: PT. Alfabeta. 